\title{
Pragmatic Competence in Requests, Apologies and Refusals: A Study on Universiti Teknologi Mara (UiTM) Students
}

Intan Rehana Razali, Nor Eleyana Abdullah

To Link this Article: http://dx.doi.org/10.6007/IJARBSS/v11-i10/11454

DOI:10.6007/IJARBSS/v11-i10/11454

Received: 03 August 2021, Revised: 25 August 2021, Accepted: 19 September 2021

Published Online: 20 October 2021

In-Text Citation: (Razali \& Abdullah, 2021)

To Cite this Article: Razali, I. R., \& Abdullah, N. E. (2021). Pragmatic Competence in Requests, Apologies and Refusals: A Study on Universiti Teknologi Mara (UiTM) Students. International Journal of Academic Research in Business and Social Sciences, 11(10), 847-859.

\section{Copyright: (c) 2021 The Author(s)}

Published by Human Resource Management Academic Research Society (www.hrmars.com) This article is published under the Creative Commons Attribution (CC BY 4.0) license. Anyone may reproduce, distribute, translate and create derivative works of this article (for both commercial and non-commercial purposes), subject to full attribution to the original publication and authors. The full terms of this license may be seen at: http://creativecommons.org/licences/by/4.0/legalcode

$$
\text { Vol. 11, No. 10, 2021, Pg. } 847 \text { - } 859
$$

Full Terms \& Conditions of access and use can be found at http://hrmars.com/index.php/pages/detail/publication-ethics 


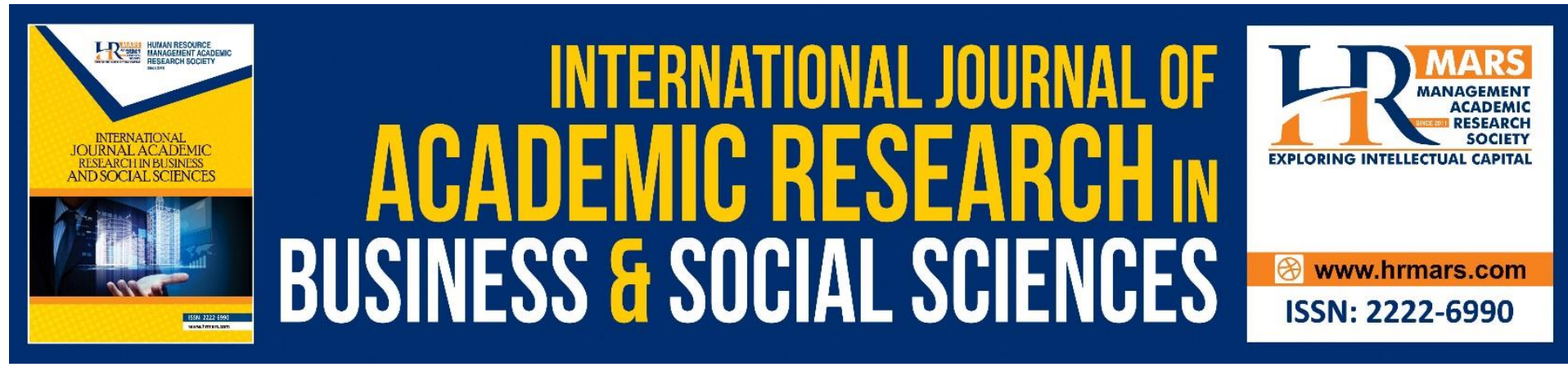

\title{
Pragmatic Competence in Requests, Apologies and Refusals: A Study on Universiti Teknologi Mara (UiTM) Students
}

\author{
Intan Rehana Razali ${ }^{1}$, Nor Eleyana Abdullah ${ }^{2}$ \\ ${ }^{1}$ The Academy of Language Studies, Universiti Teknologi MARA, 40450 Shah Alam, Selangor \\ Darul Ehsan, ${ }^{2}$ The Academy of Language Studies, Universiti Teknologi MARA, 40450 Shah \\ Alam, Selangor Darul Ehsan. \\ Email: intanrehana282@gmail.com, eleyanaabdullah@uitm.edu.my
}

\begin{abstract}
Pragmatic competence is the ability to understand and responding appropriately to the context of utterances (Farashaiyan \& Muthusamy, 2016). Without it, disruptions in communication will occur and this will result in pragmatic failure. In correlation, studies have found out that English as a Second Language (ESL) students, albeit being in the targeted language environment (ESL), they still experience pragmatic incompetence (Wyner, 2014). Thus, this paper aims to identify the level of pragmatic competence among non-English majors at Universiti Teknologi Mara (UiTM) using the theoretical framework of request and apology by Blum-Kulka and Olshtain (1984) and refusal by Beebe et al. (1990). Next, the analytical framework is adopted from Al-Aghbari (2016). Qualitatively, a discourse completion task (DCT) with nine different scenarios using three different speech acts was distributed to 41 UiTM students who have at least completed an English course in UiTM. The findings suggest that the students are identified to possess an intermediate level of pragmatic competence. However, some parts of their responses are still considered as inappropriate in the social standards while using the English language. It is hoped that this study contributes more insights into pragmatics, especially on pragmatic competence in ESL context among university students and is also useful and helpful for other similar studies in the future.
\end{abstract}

Keywords: Pragmatic Competence, Speech Act Theory, Request, Refusal, Apology

\section{Introduction}

According to Yule (1996), pragmatics is defined as the study of meaning as uttered by a speaker and interpreted by a listener. Meanwhile, according to Kasper (2001), as cited in Krisnawati (p. 106, 2011), pragmatic competence is defined as "the study of language from the point of view of users, especially of the choices they make, the constraints they encounter in using language in social interaction and the effects their use of language has on other participants in the act of communication." A lot of studies involving pragmatic competency involving ESL and EFL students often revealed that the former group possess greater pragmatic competency and awareness compared to the latter (Altheeby, 2018). Although the problem is more prevalent among EFL students, competency cannot be measured based 
solely on setting or, if one of the contributing factors to pragmatic competence is environment, then, living and learning in an ESL environment would benefit the students more.

To put into perspective, studies have also found that ESL students, albeit being in the targeted language environment (ESL), they still experience pragmatic incompetence (Wyner, 2014). Schauer (2006) in her study on Pragmatic Awareness between ESL and EFL context exposed that ESL students perceived pragmatic incompetency led to more errors compared to the grammatical one. This could be due to the fact that the teaching and learning of English education often revolves around textbooks, language laboratories, e-learning, which lacks the authenticity of the language in context (Jaekel, 2020). Consequently, it may affect the development of the communicative requirement, in this case, the pragmatic awareness and competence among the undergraduates. Hence, pragmatic competence in ESL learning is crucial for L2 students to truly understand the context of utterances, specifically in the communicative settings between their peers and educators. This is to ensure a smooth communication process between the speaker and the hearer. Therefore, the need to gauge on their level of pragmatic competence is crucial to assess on the development of their communicative competence. Hence, this study attempts to identify the level of pragmatic competence among UiTM students based on this research question:

1. What is the level of pragmatic competence among UiTM students?

\section{Literature Review \\ Pragmatic Competence}

Pragmatics is the study of language from the point of view of the users, especially of the choices they make, the constraints they encounter in using language in social interaction and the effects of their use of language has on other participants in the act of communication, (Kasper, 2001). Besides that, pragmatics also consists of conventional rules of language which are manifested in the production and interpretation of utterances, (Rajabia et al., 2015). The conventional rules help the speakers in analysing the context of speech, hence, will enable the speakers to apply the most appropriate and acceptable replies. Subsequently, pragmatic competence is the most vital aspect of communicative competence. It is crucial in ensuring successful interaction. Most researchers define pragmatic competence within the similar context, which is adapted from Kasper. As interpreted by Rajabia et al (2015), pragmatic competence is the ability to use language appropriately according to contextual factors. Most non-native speakers could speak well in a sense that they could articulate words the same way and as precisely as native speakers. However, they tend to disregard the conventional rules in pragmatics. As a result, their utterances may be observed as rude or meaningless, (Rajabia et al., 2015).

\section{Speech Acts Theories}

The classifications of speech acts of requests and apologies by Blum-Kulka and Olshtain (1984), have been applied widely in analysing the pragmatic competence of certain groups in studies, (Alzeebaree \& Yavuz, 2017). First and foremost, the classification of the request strategies modelled by Blum-Kulka and Olshtain (1984), consists of three degrees of directness; direct, conventionally indirect, and non-conventionally indirect (see findings section). According to Alzeebaree and Yavuz (2017), the level of directness used in requests among speakers differ according to their pragmatic knowledge as well as their ability to 
understand the contextual meaning of utterances. Therefore, the speakers' level of pragmatic competence plays a big role in determining their responses and directness in requests.

Next, Blum-Kulka and Olshtain (1984), as cited in Al-Aghbari (2016), classified apology strategies into five categories which are 'an expression of an apology', 'an explanation or account of the situation', 'an acknowledgement of responsibility', 'an offer of repair', and 'a promise of forbearance' (see findings section). Speakers of different levels of pragmatic understanding would employ different categories of apology which caters to sustaining relationships. According to Ezzaoua (2020), apology is a type of speech act which aims to maintain social relationships and to restore harmony between a speaker and the hearer.

Finally, according to Sattar et al (2012); Beebe et al.'s (1990) analysis and classification of refusals has been used widely in the studies of pragmatics and speech acts. Beebe et al. (1990), categorised the classification of refusals into two categories: direct and indirect (see findings section). This model captures not only the different degrees of directness and indirectness in refusals, but also focuses on the differences in the content of excuses provided. Beebe et al. (1990) defined refusal as "a significant diverse 'sticking point' for some foreign-language speakers". Most non-native speakers find that announcing refusals are complicated as they fear to be wrong, (Fitri et al., 2020). Hence, sufficient pragmatic development is necessary in oneself when refusing or announcing their refusals.

\section{Methods}

This study has adopted a qualitative research design. A discourse completion task (DCT) is distributed to 41 non-English majors in UiTM across Malaysia. The DCT consists of nine different scenarios using three different speech acts of requests, apologies, and refusals. Next, The DCT is formulated on Google form and the link to it is shared through online platforms. Through convenience sampling, the DCT respondents are assembled virtually at a different staging and timeline for this study. The participants' responded DCTs are collected and organised accordingly. Next, the data collected are analysed based on the analytical framework adapted from Al-Aghbari's (2016) study. The responses collected from the DCT of the speech acts of Request and Apology are classified according to Blum-Kulka and Olshtain's (1984) classifications of request and apology strategies, while the data for the speech act of Refusal are classified based on Beebe et al.'s (1990).

\section{Results/ Findings \\ Data of the Speech Act of Request}

The table below shows the descriptive view of each strategy in the classifications of the request head act. According to the following table, there are nine strategies in making requests. These nine strategies were then categorised into three different tiers and levels of: direct, conventionally indirect, and non-conventionally indirect. 
Table 1 : Classification of Request Strategies

\begin{tabular}{|c|c|}
\hline Level of Directness & Strategy Type \\
\hline \multirow[t]{5}{*}{ Direct } & $\begin{array}{l}\text { Mood derivable: an utterance in which the } \\
\text { grammatical mood of the verb signals illocutionary } \\
\text { force (Leave me alone) }\end{array}$ \\
\hline & $\begin{array}{l}\text { Explicit performative: an utterance in which the } \\
\text { illocutionary force is explicitly named (I am asking } \\
\text { you to clean up the mess) }\end{array}$ \\
\hline & $\begin{array}{l}\text { Hedged performative: an utterance in which the } \\
\text { naming of the illocutionary force is modified by } \\
\text { hedging expressions (I would like to ask you to give } \\
\text { your presentation a week earlier than scheduled) }\end{array}$ \\
\hline & $\begin{array}{l}\text { Obligation statement: an utterance which states the } \\
\text { obligation of the hearer to carry out the act (You'll } \\
\text { have to move that car) }\end{array}$ \\
\hline & $\begin{array}{l}\text { Want statement: an utterance which states the } \\
\text { speaker's desire that the hearer carries out the act (I } \\
\text { really wish you'd stop bothering me) }\end{array}$ \\
\hline \multirow[t]{2}{*}{ Conventionally Indirect } & $\begin{array}{l}\text { Suggestory formula: an utterance which contains a } \\
\text { suggestion to do (How about cleaning up?) }\end{array}$ \\
\hline & $\begin{array}{l}\text { Query preparatory: an utterance containing } \\
\text { reference to preparatory conditions such as ability, } \\
\text { possibility, willingness and permission as } \\
\text { conventionalised in any specific language (Could you } \\
\text { clean up the kitchen, please?) }\end{array}$ \\
\hline \multirow[t]{2}{*}{ Non-conventionally Indirect } & $\begin{array}{l}\text { Strong hint: an utterance containing partial } \\
\text { reference to object or element needed for the } \\
\text { implementation of the act (You have left the kitchen } \\
\text { in a right mess) }\end{array}$ \\
\hline & $\begin{array}{l}\text { Mild hint: an utterance that makes no reference to } \\
\text { the request proper or any of its elements but are } \\
\text { interpretable as requests by context (You've been } \\
\text { busy here, haven't you?) }\end{array}$ \\
\hline
\end{tabular}

In this study, the respondents were required to announce their requests according to the following situations:

Situation 1: Your assignment is due tonight, but you haven't finished it yet. You want to ask your lecturer/instructor for an extension. What do you say:

Situation 6: You are assigned to do an interview with one of your lecturers for your faculty's yearly magazine. How would you announce your request?

Situation 9: You are on your first day of the new semester and you found yourself lost on your way to the meeting room at the new Administration Building. You are unsure of the location of the exact meeting room. You want to ask for the location from a classmate you just met. You say:

The following table presents the strategies applied by the respondents in each situation of making requests: Situation 1, Situation 6 and Situation 9. The grey area in table indicates null application of the strategy 
Table 2 : Type and Frequency of Request Strategies

\begin{tabular}{|c|c|c|c|c|c|c|c|}
\hline \multicolumn{2}{|l|}{ Strategy Type } & \multicolumn{2}{|c|}{ Sit. 1} & \multicolumn{2}{|c|}{ Sit. 6} & \multicolumn{2}{|c|}{ Sit. 9} \\
\hline & & $\begin{array}{l}\text { Fre } \\
\mathbf{q}\end{array}$ & $\begin{array}{l}\text { Per } \\
(\%)\end{array}$ & $\begin{array}{l}\text { Fre } \\
q\end{array}$ & $\begin{array}{l}\text { Per } \\
(\%)\end{array}$ & $\begin{array}{l}\text { Fre } \\
\mathbf{q}\end{array}$ & $\begin{array}{l}\text { Per } \\
(\%)\end{array}$ \\
\hline \multirow[t]{4}{*}{ Direct } & Mood derivable & 1 & $2.44 \%$ & & & & \\
\hline & Want statement & 3 & $7.31 \%$ & 4 & $9.76 \%$ & & \\
\hline & $\begin{array}{l}\text { Explicit } \\
\text { Performative }\end{array}$ & 1 & $2.44 \%$ & 1 & $2.44 \%$ & 3 & $7.31 \%$ \\
\hline & $\begin{array}{l}\text { Hedged } \\
\text { Performative }\end{array}$ & 4 & $9.76 \%$ & 2 & $4.88 \%$ & 1 & $2.44 \%$ \\
\hline \multirow[t]{2}{*}{ Conventionally Indirect } & $\begin{array}{l}\text { Suggestory } \\
\text { formula }\end{array}$ & 2 & $4.88 \%$ & 5 & $12.2 \%$ & 10 & $24.4 \%$ \\
\hline & $\begin{array}{l}\text { Query } \\
\text { preparatory }\end{array}$ & 25 & $61.0 \%$ & 23 & $56.1 \%$ & 27 & $65.9 \%$ \\
\hline \multirow{2}{*}{$\begin{array}{l}\text { Non-conventionally } \\
\text { Indirect }\end{array}$} & Strong Hint & 2 & $4.88 \%$ & & & & \\
\hline & Mild Hint & 2 & $4.88 \%$ & 2 & $4.88 \%$ & & \\
\hline No request & & 1 & $2.44 \%$ & 4 & $9.76 \%$ & & \\
\hline
\end{tabular}

As introduced previously, Table 2 presents the strategies applied by the respondents in making requests for the Discourse Completion Task. From the table above, the most recurrent strategy is the "query preparatory" in all three situations. The summary of this is illustrated in the table below:

Table 3: Summary of the highest use of Request Strategies

\begin{tabular}{ll}
\hline Situations & Percentage (\%) - The highest \\
\hline Sit. 1 (Request for an extension from the lecturer) & $\begin{array}{l}\text { (Conventionally Indirect) } \\
\text { Query preparatory - 61.0\% } \\
\text { (Conventionally Indirect) }\end{array}$ \\
Sit. 6 (Request for an interview session with lecturer) & $\begin{array}{l}\text { Query preparatory - 56.1\% } \\
\text { (Conventionally Indirect) } \\
\text { Sit. } 9 \text { (Request for a location from a classmate) }\end{array}$ \\
& Query preparatory - 65.9\%
\end{tabular}

Based on Table 3, the overall strategy of "query preparatory" was applied the most frequently among students in announcing their requests for all three different situations. As explained by Blum-Kulka and Olshtain (1984), this particular strategy is categorised under the level of conventionally indirect. Hence, Malaysian students especially UiTM undergraduates are found to be more inclined in applying this conventionally indirect level in their speech especially in making requests. As for the "query preparatory" strategy type, the relevancy of applying this in one's speech act is due to its contained reference to preparatory conditions for example, ability, possibility, willingness and permission. Thus, most students may have 
viewed that in making requests it should always be regarding them asking for permission or possibility.

In relation to that matter, the observation has discovered that the UiTM students' responses are almost similar to one another in the aspect of the usage of word "could/can" inserted in their utterances. The usage of "could/can" was used to mitigate the requests. Exemplified below are the responses with the mitigation of "could/can":

- Can you extend the submission date?

- Can I send it a bit late?

- Can I interview you when you are free?

- Could I arrange a meeting with you on Monday at $2 \mathrm{pm}$ for an interview?

The use of "could/can" occurred more frequently in situation 1 and 6 where the requests are intended for a higher status (for the lecturer) as a way to appeal more softly and to soften the effect of the speech act, (Al-Aghbari, 2016). However, the presence of "can" precedes "could" which could also flag the respondents' lack of pragmatic awareness on politeness.

\section{Data of the Speech Act of Apology}

The respondents of the DCT were required to apologise according to three dissimilar situations. As constructed below is the Table 4 of the classifications of strategies in apology by Blum-Kulka and Olshtain, (1984). This specific classifications of strategy for the apology speech act will be sampled in analysing the responses submitted by the students.

Table 4 - Classification of Apology Strategies

\begin{tabular}{ll}
\hline Strategy & Sub-Strategy \\
\hline An expression of an apology & An expression of regret, e.g., I'm sorry \\
& An offer of apology, e.g., I apologise \\
& A request for forgiveness, e.g., Excuse me, Please, \\
forgive me, or Pardon me
\end{tabular}

An explanation or account of the situation

An acknowledgement of Accepting the blame, e.g., It is my fault responsibility

Expressing self-deficiency, e.g., I was confused, I wasn't thinking, I didn't see you

Expressing lack of intent, e.g., I didn't mean to

An offer of repair

A promise of forbearance

Following the students' responses in this speech act of apology, three situations with different context were employed in the DCT. The following list are the situations in which the students were obligated to state their apologies and to apologise.

Situation 2: In an online class, you did not respond to your lecturer's question. Your lecturer is still calling out your name. How do you apologise to your lecturer?

Situation 5: You broke your mother's favourite coffee cup while doing the dishes. Your mother found out about it, and she was very upset. How do you apologise to your mother?

Situation 8: "Where are you? Didn't you receive the text regarding our meeting? We have waited for you for almost an hour. Are you coming?" Your classmate called and said this on 
the phone. You misread the text, thinking that the meeting will be held tomorrow. How would you apologise to your friend, on the phone?

The following table presents the strategies applied by the respondents in each situation of apologising: Situation 2, Situation 5 and Situation 8. The grey area in Table 5 indicates null application of the strategy.

Table 5 - Type and Frequency of Apology Strategies

\begin{tabular}{|l|l|l|l|l|l|l|}
\hline \multirow{2}{*}{ Strategy Type } & \multicolumn{2}{l|}{ Sit. 2 } & \multicolumn{2}{l|}{ Sit. 5 } & \multicolumn{2}{l|}{ Sit. 8 } \\
\cline { 2 - 8 } & Freq & Per (\%) & Freq & Per (\%) & Freq & Per (\%) \\
\hline An expression of apology & 14 & $34.15 \%$ & 6 & $14.63 \%$ & 5 & $21.2 \%$ \\
\hline $\begin{array}{l}\text { An explanation or account of the } \\
\text { situation }\end{array}$ & 17 & $41.47 \%$ & 1 & $2.44 \%$ & 1 & $2.44 \%$ \\
\hline An acknowledgement of responsibility & 8 & $19.5 \%$ & 8 & $19.5 \%$ & 14 & $34.15 \%$ \\
\hline A promise of forbearance & 1 & $2.44 \%$ & 3 & $7.32 \%$ & & \\
\hline An offer of repair & & & 23 & $56.1 \%$ & 21 & $51.22 \%$ \\
\hline No apology & 1 & $2.44 \%$ & & & & \\
\hline
\end{tabular}

As can be observed from the data above, the strategy with highest recurrent in the three situations are tabulated in Table 6:

Table 6: Summary of the highest use of Apology Strategies

\begin{tabular}{|c|c|}
\hline Situation & Percentage (\%) - The highest \\
\hline $\begin{array}{l}\text { Sit. } 2 \text { (Apology to the lecturer for not } \\
\text { responding) }\end{array}$ & $\begin{array}{l}\text { An explanation or account of the } \\
\text { situation }-41.7 \%\end{array}$ \\
\hline $\begin{array}{l}\text { Sit. } 5 \text { (Apology to the mother for breaking her } \\
\text { cup) }\end{array}$ & An offer of repair - $56.1 \%$ \\
\hline $\begin{array}{l}\text { Sit. } 8 \text { (Apology to a friend for not coming to the } \\
\text { discussion) }\end{array}$ & An offer of repair $-51.22 \%$ \\
\hline
\end{tabular}

In Table 6, the strategy of "An offer of repair" was widely used by the students in situation 5 and 8 . In situation 5 , most students apologised and offered a repair to the hearer by offering to make replacement to the broken cups.

For example:

\section{Situation 5}

- I will buy a new one for you

- I promise l'll buy the new one

- I'll buy you another same cup

- Maybe we can go and get a new one?

From the responses above, it can be identified that students were trying to make appeal towards the hearers by offering them a repair. It is expected that there could be an occurrence 
of diversion in the responses of the hearers. For instance, instead of getting mad, the hearers will most likely just take the offering as settlement.

\section{Data of the Speech Act of Refusal}

In this study, Beebe et al.'s (1990) description of direct and indirect strategies for refusals will be used in analysing the respondents' refusals in the DCT. The classification of refusal strategies by Beebe et al (1990) is prompted below.

Table 7 : Classification of Refusal Strategies

\begin{tabular}{lll}
\hline Level of & Strategy Type \\
Directness & & \\
\hline
\end{tabular}

$\begin{array}{ll}\text { Direct } & \text { A. Performative (e.g., "I refuse") } \\ & \text { B. Non-performative statement }\end{array}$

1. No"

2. Negative willingness/ability ("I can't." "I won't." "I don't think so."

Indirect $\quad$ A. Statement of regret (e.g., I'm sorry...". "I feel terrible...")

B. Wish (e.g., "I wish I could help you...")

C. Excuse, reason, explanation (e.g., "My children will be home that night", "I have a headache"

D. Statement of alternative

1. I can do $X$ instead of $Y$ (e.g., "I'd rather...", "I'd prefer")

2. Why don't you do $X$ instead of $Y$ (e.g., "Why don't you ask someone else?")

E. Set condition for future or past acceptance (e.g., "If you had asked me earlier, I would have...")

F. Promise of future acceptance (e.g., "I'Il do it next time" ; "I promise I'll..." or "Next time I'll..." -using "will" of promise or "promise")

G. Statement of principle (e.g., "I never do business with friends."

H. Statement of philosophy (e.g., "One can't be too careful."

I. Attempt to dissuade interlocutor

1. Threat or statement of negative consequences to the requester (e.g., "I won't be any fun tonight" to refuse an invitation)

2. Guilt trip (e.g., waitress to customers who want to sit a while: "I can't make a living off people who just order coffee."

3. Criticise the request/requester and et cetera. (statement of negative feeling or opinion); insult/attack (e.g., "Who do you think you are?"; "That's a terrible idea!")

4. Request for help, empathy, and assistance by dropping or holding the request.

5. Let interlocutor off the hook (e.g., "Don't worry about it."; "That's okay."; "You don't have to.")

6. Self-defense (e.g., "I'm trying my best."; "I'm doing all I can."

J. Acceptance that functions as a refusal 


\author{
1. Unspecific or indefinite reply \\ 2. Lack of enthusiasm \\ K. Avoidance \\ 1. Nonverbal
a) Silence
b) Hesitation
c) Do nothing
d) Physical departure \\ 2. Verbal
a) Topic switch
b) Joke
c) Repetition of part of request and et cetera. (e.g., "Monday?")
d) Postponement (e.g., "I'll think about it.")
e) Hedging (e.g., "Gee, I don't know."; "I'm not sure.")
Adjuncts to 1 . Statement of positive opinions/feeling or agreement ("That's a Refusals good idea..."”; "I'd love to...")
2. Statement of empathy (e.g., "I realise you are in a difficult situation.")
3. Pause filter (e.g., "uhhh"; "well"; "uhm")
4. Gratitude/appreciation

In this study, it is compulsory for students to refuse in three different situations inquired in the DCT. The following presents the three situations with different contexts.

Situation 3: You just met a new friend online; he invites you and some of your other friends to his new house tomorrow for lunch. You can't attend as you are required to accompany your parents to the hospital. You refuse by saying?

Situation 4: You have just completed an online test and managed to submit it earlier than your classmates. Your classmates texted you asking if he could copy everything from your submitted paper. How would you refuse in this situation?

Situation 7: You are a final year student who is very occupied with tasks and assignments. Somehow, you are invited by the students' council to become your class' representative. Unfortunately, you must refuse as you have other commitments. What do you say:

The following table presents the strategies applied by the respondents in each situation of refusing: Situation 3, Situation 4 and Situation 7 . The grey area in table indicates null application of the strategy. 
Table 8 : Type and Frequency of Refusal Strategies

\begin{tabular}{|c|c|c|c|c|c|c|c|}
\hline \multicolumn{2}{|l|}{ Strategies } & \multicolumn{2}{|l|}{ Sit. 3} & \multicolumn{2}{|c|}{ Sit. 4} & \multicolumn{2}{|c|}{ Sit. 7} \\
\hline & & \multirow[t]{2}{*}{ Freq } & \multirow[t]{2}{*}{$\begin{array}{l}\text { Per } \\
(\%)\end{array}$} & \multirow{2}{*}{$\begin{array}{l}\text { Fre } \\
\mathbf{q} \\
3\end{array}$} & \multirow{2}{*}{$\begin{array}{l}\text { Per } \\
\text { (\%) }\end{array}$} & \multirow{2}{*}{$\begin{array}{l}\text { Fre } \\
\mathbf{q} \\
1\end{array}$} & \multirow{2}{*}{$\begin{array}{l}\text { Per } \\
(\%)\end{array}$} \\
\hline Direct & No & & & & & & \\
\hline & $\begin{array}{l}\text { Negative } \\
\text { willingness/ability }\end{array}$ & 5 & $\begin{array}{l}12.2 \\
\%\end{array}$ & 4 & $\begin{array}{l}9.75 \\
\%\end{array}$ & 6 & $\begin{array}{l}14.63 \\
\%\end{array}$ \\
\hline \multirow[t]{7}{*}{ Indirect } & Statement of regret & 4 & $\begin{array}{l}9.75 \\
\%\end{array}$ & 8 & $\begin{array}{l}19.51 \\
\%\end{array}$ & 12 & $\begin{array}{l}29.27 \\
\%\end{array}$ \\
\hline & $\begin{array}{l}\text { Excuse, } \\
\text { explanation }\end{array}$ & 19 & $\begin{array}{l}46.34 \\
\%\end{array}$ & 1 & $\begin{array}{l}2.44 \\
\%\end{array}$ & 11 & $\begin{array}{l}26.83 \\
\%\end{array}$ \\
\hline & Statement of alternative & & & 9 & $\begin{array}{l}22.00 \\
\%\end{array}$ & 5 & $\begin{array}{l}12.2 \\
\%\end{array}$ \\
\hline & $\begin{array}{l}\text { Set condition for future of } \\
\text { past }\end{array}$ & & & 2 & $\begin{array}{l}4.88 \\
\%\end{array}$ & & \\
\hline & $\begin{array}{l}\text { Attempt to dissuade } \\
\text { interlocutor }\end{array}$ & & & 9 & $\begin{array}{l}22.00 \\
\%\end{array}$ & 1 & $\begin{array}{l}2.44 \\
\%\end{array}$ \\
\hline & $\begin{array}{l}\text { Promise for future } \\
\text { acceptance }\end{array}$ & 13 & $\begin{array}{l}31.71 \\
\%\end{array}$ & & & & \\
\hline & $\begin{array}{l}\text { Avoidance/Silence/Joke/ } \\
\text { Topic Switch }\end{array}$ & & & 3 & $\begin{array}{l}7.32 \\
\%\end{array}$ & & \\
\hline $\begin{array}{l}\text { Adjuncts to } \\
\text { Refusals }\end{array}$ & $\begin{array}{l}\text { Statement of positive } \\
\text { opinions/ feeling or } \\
\text { agreement }\end{array}$ & & & & & 4 & $\begin{array}{l}9.76 \\
\%\end{array}$ \\
\hline \multicolumn{2}{|l|}{ No refusal } & & & 2 & $\begin{array}{l}4.77 \\
\%\end{array}$ & 1 & $\begin{array}{l}2.44 \\
\%\end{array}$ \\
\hline
\end{tabular}

According to the data, the most frequent strategies used by the respondents throughout the situations are "Excuse/reason", "Statement of regret" and "Negative willingness". Although, it can be seen from the data that there is a high percentage of $31.71 \%$ for the "Promise for future acceptance", it should be noted that, this strategy is only ideal for situation 3 . In other situations, no applications of this strategy were used by the respondents. 
The most recurrent strategy in all three situations is in the table below:

Table 9 : Summary of the highest use of Refusal Strategies

\begin{tabular}{ll} 
Situation & Percentage (\%) - The highest \\
\hline Sit. 3 (Refuse to a new friend's invitation) & $\begin{array}{l}\text { (Indirect) } \\
\text { Promise for future acceptance - } \\
31.71 \% \%\end{array}$ \\
Sit. 4 (Refuse to a classmate's permission to copy your & $\begin{array}{l}\text { (Indirect) } \\
\text { Statement of Alternative }-22.0 \% \\
\text { work) }\end{array}$ \\
& $\begin{array}{l}\text { Attempt to dissuade interlocutor - } \\
22.0 \% \\
\text { (Conventionally Indirect) }\end{array}$ \\
Sit. 7 (Refuse to an offer to become the class & Statement of regret - $29.27 \% \%$
\end{tabular}

As mentioned previously, the strategy of "Promise for future acceptance" was applied the most in situation 3 with the percentage of $31.71 \%$. This occurred due as students were required to refuse or decline an invitation to a friend's house. Hence, in this case, students actually had options to use "Promise for future acceptance" as refusals. For example:

- I can't go cause I have to follow my parents to the hospital. Maybe later.

- I'm really appreciate this, but I already have another plan at that time, maybe we can go for lunch another time.

- Ah sorry guys, I gotta accompany my parents to the hospital. I'll catch up soon.

From the responses above, the respondents were refusing by telling the hearer that they have some other commitments during the time of the event. However, they can eventually plan out for other hangouts in the future when they are no longer occupied with commitments. In the responses, there are indicators such as "will", "later", "another time". Hence, the application of the "Promise for future acceptance" strategy.

\section{Conclusions}

To conclude, there is an indication of intermediate level of pragmatic competence among UiTM students. These non-English majors in UiTM are capable in applying the correct strategies of speech acts when they request, refuse, and apologise. This indicates that, the students do have the knowledge required in responding to different situations of dissimilar speech acts. However, there seemed to be some parts of the responses in which, are considered as inappropriate in the social standards while using the English language. It is also found out that the respondents' choice of words in some strategies exemplify their low level of politeness, which is one of the crucial skills in becoming pragmatically competent. Besides that, various language errors are also present in the respondents' DCT responses. Hence it is agreeable with previous studies that ESL students, albeit being in the targeted language environment (ESL), they still experience pragmatic incompetence and ESL students perceived pragmatic incompetency led to more errors compared to the grammatical one (Wyner, 2014; Schauer, 2006). Lastly, it is recommended for future researchers to incorporate other speech acts as the research would be more extensive and wide-ranging. Moreover, further research into the awareness of pragmatic competence and looking into the importance of developing pragmatic competence in ESL context among English-major undergraduates or graduates could also be initiated for further development of future research. 


\section{References}

Al-Aghbari, D. (2016). Integrating pragmatic competence in teaching English to the students of medicine at Taiz University (Doctoral dissertation, université de Strasbourg). https://tel.archives-ouvertes.fr/tel-01494800

Altheeby, M. (2018). Differences in the pragmatic competence of Saudi EFL and ESL learners (Doctoral dissertation, Cardiff University).

Alzeebaree, Y., \& Yavuz, M. A. (2017). Realization of the speech acts of request and apology by middle eastern EFL learners. Eurasia Journal of Mathematics, Science and Technology Education, 13(11), 7313-7327. https://doi.org/10.12973/ejmste/79603

Beebe, L. M., Takahashi, T., \& Uliss-Weltz, R. (1990). Pragmatic transfer in ESL refusals. Developing communicative competence in a second language, 5573.

Blum-Kulka, S., \& Olshtain, E. (1984). Requests and apologies: A cross-cultural study of speech act realization patterns (CCSARP). Applied linguistics, 5(3), 196-213. https://10.1093/applin/5.3.196

Ezzaoua, O. (2020). Apologies in EFL: An Interlanguage Pragmatic Study on Moroccan Learners of English. Studies in Literature and Language, 20(2), 1-8.

Farashaiyan, A., \& Muthusamy, P. (2016). Pragmatic Variations in Giving Advice in L2 by Malaysian Postgraduate Students: The Situational Effects. English Language Teaching, 9(5), 179-191.

Fitri, A., Muslem, A., \& Marhaban, S. (2020). The investigation of refusal strategies used by university students of English department. English Education Journal, 11(4), 453-465.

Jaekel, N. (2020). Language learning strategy use in context: the effects of self-efficacy and CLIL on language proficiency. International Review of Applied Linguistics in Language Teaching, 58(2), 195-220.

Kasper, G. (2001). Four perspectives on L2 pragmatic development. Applied linguistics, 22(4), 502-530. https://doi.org/10.1093/applin/22.4.502

Krisnawati, E. (2011). Pragmatic competence in the spoken English classroom. Indonesian Journal of Applied Linguistics, 1(1), 105-115. https://doi.org/10.17509/ijal.v1i1.102

Rajabia, S., Azizifara, A., \& Gowhary, H. (2015). The effect of explicit instruction on pragmatic competence development; teaching requests to EFL learners of English. Procedia-Social and Behavioral Sciences, 199, 231-239. https://doi.org/10.1016/j.sbspro.2015.07.511

Sattar, H. Q. A., Lah, S. C., \& Suleiman, R. R. R. (2012). Refusal strategies in English by Malay university students. GEMA Online ${ }^{\circledR}$ Journal of Language Studies, 11(3).

Schauer, G. A. (2006). Pragmatic awareness in ESL and EFL contexts: Contrast and development. Language learning, 56(2), 269-318._https://doi.org/10.1111/j.00238333.2006.00348.x

Wyner, L. (2014). Second Language Pragmatic Competence: Individual Differences in ESL and EFL Environments. Working Papers in TESOL \& Applied Linguistics, 14(2), 84-99. https://files.eric.ed.gov/fulltext/EJ1176870.pdf

Yule, G. (1996). Pragmatics. New York: Oxford University Press. 